\title{
OCCUPATIONAL ALLERGY TO BIRDS WITHIN THE POPULATION OF POLISH BIRD KEEPERS EMPLOYED IN ZOO GARDENS
}

\author{
SYLWIA ŚWIDERSKA-KIEL BIK ${ }^{1}$, ANNA KRAKOWIAK ${ }^{1}$, MARTA WISZNIEWSKA ${ }^{1}$, \\ EWA NOWAKOWSKA-ŚWIRTA ${ }^{1}$, JOLANTA WALUSIAK-SKORUPA ${ }^{1}$, KONRAD ŚLIWKIEWICZ ${ }^{1}$, \\ and CEZARY PAŁCZYŃSKI ${ }^{1,2}$
}

${ }^{1}$ Nofer Institute of Occupational Medicine, Łódź, Poland

Department of Occupational Diseases and Toxicology

${ }^{2}$ Nofer Institute of Occupational Medicine, Łódź, Poland

Centre of Occupational Allergy and Environmental Health

\begin{abstract}
Objectives: To evaluate the risk factors for the development of occupational allergy to birds among Polish zoo garden keepers. Methods: A total of 200 bird zookeepers employed in the Polish zoo gardens in Łódź, Warsaw, Gdańsk, Chorzów and Płock and exposed occupationally to bird allergens were examined using a questionnaire, skin prick tests (SPTs) to common allergens and bird allergens, spirometry and cytograms of nasal swab. The level of total IgE in serum and serum-specific IgE to parrot, canary, pigeon feathers and serum were also evaluated. Results: Eight percent of bird zookeepers were sensitized to at least one of the bird allergens. The most frequent allergens yielding positive SPT results were $D$. farinae -32 cases $(16 \%)$, D. pteronyssinus - 30 cases $(15 \%)$ and grass pollens $(16.5 \%)$. In the studied group, allergen-specific IgE against bird allergens occurred with the following frequency: 87 (43.5\%) against canary feathers and/or serum, 80 (40\%) against parrot feathers and/or serum and $82(41 \%)$ against pigeon feathers and/or serum. Occupational allergy was diagnosed in $39(26.5 \%)$ cases, occupational rhinitis was present in $22(15 \%)$ cases, occupational asthma in $20(13.6 \%)$ subjects, occupational conjunctivitis in $18(12.2 \%)$ cases, whereas occupational skin diseases in $11(7.5 \%)$ cases. More eosinophils were found in nose swab cytograms among bird zookeepers with occupational airway allergy. Conclusions: The findings indicate that occupational allergy to birds is an important health problem among zoo bird keepers in Poland.
\end{abstract}

Key words:

Allergens, Birds, Allergy, Occupational exposure

\section{INTRODUCTION}

Bird allergens are an important cause of occupational allergic diseases [1-4]. Airborne contaminants in birds' cages constitute a complex mixture of aerosolized agents, consisting of organic dust-skin debris, broken feather barbules, insects' remains, aerosolized food particles, birds' excreta, ammonia, and a variety of viable bacteria, as well as airborne gram-negative bacteria and endotoxins [5,6]. Our data published in 2009 shows that subjects working with birds are also exposed to disinfectants and latex allergens (LA) [4]. In the aforementioned study we proved the significant role of family history positive for atopy and occupational contact with parrots either in the development of work-related

Received: January 19, 2011. Accepted: April 11, 2011.

Address reprint request to A. Krakowiak, Toxicology Unit, Department of Occupational Diseases and Toxicology, Nofer Institute of Occupational Medicine, Łódź, Poland (e-mail: annakrak@imp.lodz.pl). 
symptoms or work-related respiratory allergic symptoms (questionnaire data) [4].

The aim of the present study was to investigate the frequency of hypersensitivity to bird allergens and to identify the risk factors for the development of occupational allergy and occupational airway allergy among bird keepers in Polish zoo gardens.

\section{MATERIALS AND METHODS}

The studied group consisted of 200 persons (109 males and 91 females) employed at zoo gardens located in the metropolitan areas of Łódź, Warszawa, Gdańsk, Chorzów and Płock.

A field study was carried out in 2008 and it comprised a medical examination, a questionnaire survey, SPTs, spirometry, tests for total and specific antibodies in blood and cytology of nasal swab.

The study protocol gained approval of the Regional Biomedical Ethics Committee. All the participants gave their informed consent prior to the study.

The questionnaire, supervised by a physician, was adapted from the instrument developed by the International Union against Tuberculosis and Lung Disease (IUATLD) [9].

The symptoms suggestive of asthma included dyspnoea, wheezing, chest tightness or cough, the symptoms of rhinitis encompassed sneezing, rhinorrhea, mucosal edema and itching, whereas the symptoms of allergic conjunctivitis manifested in the form of redness and edema of eyelids, redness and edema of conjunctivae, lacrimation and itching.

Respiratory, nasal and eye symptoms related to the exposure to specific agents at the workplace and to those outside of it were also noted.

The issues covered by the questionnaire included also job characteristics and description of occupational exposure. The two categories of smokers and non-smokers were distinguished concerning the smoking habit. The category of smokers encompassed current smokers and ex-smokers. Current smokers were defined as the subjects who reported smoking tobacco at the time of the survey, and exsmokers as those who had smoked daily in the past and discontinued it at least one month before the survey. The non-smokers category was formed only by the subjects who had never smoked. The subjects who had had a pet in their childhood, or before the onset of the occupational contact with animals, were defined as subjects with previous exposure to animals and/or birds.

Skin prick tests (SPTs) were applied to the forearm. They consisted of the standard, commercially available common allergens including tree and grass pollens, Dermatophagoides pteronyssinus, Dermatophagoides farinae, Acarus siro, Thyrophagus putrescentiae, Lepidoglyphus destructor, feathers mixture, parrot feathers, canary feathers, molds in general, molds series I* (Alternaria tenuis, Botrytis cinerea, Cladosporium herbarum, Curvularia lunata, Helminthosporium halodes, Fusarium moniliforme) and molds series I** (Aspergillus fumigatus, Mucor mucedo, Penicillium notatum, Pullularia pullulans, Rhizopus nigricans, Serpula lacrymans), cat and dog allergens (Allergopharma, Reinbek, Germany). The negative control solution was a commercially available allergen diluent, while the positive control was a $1 \mathrm{mg} / \mathrm{ml}$ histamine dihydrochloride solution (Allergopharma). The largest wheal diameter was assessed after $15 \mathrm{~min}$. A wheal diameter of $\geq 3 \mathrm{~mm}$ and equal to or greater than half of that formed by histamine was defined as the positive one and indicated sensitization. The subjects were asked to avoid antihistamines or antidepressants for at least $72 \mathrm{~h}$ prior to testing.

Blood samples were then taken from all participants and the total serum IgE was evaluated. The total $\mathrm{IgE}$ level $>100 \mathrm{kU} / \mathrm{l}$ was considered as elevated.

Specific IgE antibodies to canary, pigeon, parrot feathers and serum were measured by the immunoenzymatic method (Allergopharma, Germany) - canary feathers (e009); parrot feathers (e010); pigeon feathers (e011); 
pigeon serum (e013); canary serum (e014); parrot serum (e016). Specific $\mathrm{IgE}$ levels $>0.35 \mathrm{kU} / \mathrm{l}$ were regarded as positive: class $1 \geq 0.35 \mathrm{kU} / 1<0.7 \mathrm{kU} / 1$ low; class $2 \geq 0.7$ $<3.5 \mathrm{kU} / 1$ mild; class $3 \geq 3.5<17.5 \mathrm{kU} / \mathrm{l}$ elevated; class $4 \geq 17.5<50 \mathrm{kU} / \mathrm{l}$ high; class $5 \geq 50 \mathrm{kU} / \mathrm{l}$ very high.

Spirometry was performed in all the subjects. Additionally, a nose swab was taken using the traditional approach, and cytograms from nose swabs were evaluated after coloring them with the MGG (May-Grunwald-Giemsa) method.

\section{Definitions}

Nasal symptoms and/or symptoms from the low respiratory tract formed the category defined as respiratory symptoms [7].

Allergic sensitization to birds was recognized when at least one positive result of SPTs or allergen-specific serum IgE (asIgE) to bird allergens (at least in the 1st class) occurred $[7,8]$.

Occupational allergy was defined as work-related allergy symptoms coexistent with the presence of allergic sensitization [9].

Occupational bird allergic rhinitis was specified as workrelated specific symptoms and the presence of allergic sensitization [9].

Occupational bird allergic asthma was characterized as occurrence of work-related specific symptoms along with the presence of allergic sensitization.

\section{Statistical analysis}

Continuous variables were expressed as mean values \pm standard deviations (SD), while nominal variables as numbers and percentages. Odds ratio (OR) with $95 \%$ confidence interval was calculated for all the risk factors examined, and separately for the following outcomes: workrelated allergic symptoms, work-related sensitization to bird allergens, occupational allergy to birds, occupational airway allergy to birds using EPI INFO software (CDC, Atlanta, GA, USA). Factors found to be significant in the univariate analysis were included into the multivariate logisitic regression model (Statistica 99) to predict each of the different outcomes. The $\mathrm{p}$ value below 0.05 was adopted as the reference for the selection of significant risk factors.

\section{RESULTS}

\section{Study population characteristics}

The mean age of the investigated group was $43.27 \pm 13.59$ years, whereas the mean duration of exposure to occupational allergens lasted $16.23 \pm 12.08$ years (min. 3 months; max. 50 years) (Table 1). Most of the subjects participating in the study, namely 122 workers (61\%), had a history positive for smoking (Table 1). Family history positive for atopy was reported by 58 persons (29\%). A current contact with an animal at home was recorded in 137 cases $(68.5 \%)-45$ workers $(22.5 \%)$ confirmed the contact with a cat, $102(51 \%)$ with a dog, $23(11.5 \%)$ with a parrot, $16(8 \%)$ with a canary and 16 subjects $(8 \%)$ with other birds (duck, goose, hen, pigeon and birds of prey), respectively. All questionnaire responses concerning exposure to animals and birds at present and in the past are shown in Table 1. In total, 131 workers (65.5\%) informed about the previous contact with an animal mentioned in the questionnaire. In particular: 55 subjects $(27.5 \%)$ reported having contact with a cat, 96 (48\%) with a dog, 39 (19.5\%) with a parrot, $19(9.5 \%)$ with a canary and 30 workers (15\%) with other birds. 148 workers $(74 \%)$ used latex gloves in the workplace, and 139 workers $(69.5 \%)$ were occupationally exposed to disinfectants while cleaning the cages (Table 1).

\section{Hypersensitivity to bird allergens}

The outcomes of SPTs are presented in Table 2. A total of $32.5 \%$ (65) of the subjects revealed at least one positive SPT response to common allergens. In the total study population, the most frequent allergens yielding 
Table 1. Study population characteristics

\begin{tabular}{|c|c|}
\hline Analyzed parameter & $\begin{array}{c}\text { Subjects }(\mathrm{N}=200) \\
\mathrm{n}(\%)\end{array}$ \\
\hline Age (mean \pm SD) (years) & $43.27 \pm 13.59$ \\
\hline Sex ratio: men/women & 109:91 (54.5:45.5) \\
\hline Duration of work with birds (mean $\pm S D$ ) (years) & $\begin{array}{c}16.23 \pm 12.08 \\
\text { (min. } 3 \text { months; max. } 50 \text { years) }\end{array}$ \\
\hline$\leq 5$ & $40(20.0)$ \\
\hline $6 \leq 10$ & $33(19.5)$ \\
\hline$\geq 11$ & $121(60.5)$ \\
\hline \multicolumn{2}{|l|}{ Smoking status } \\
\hline current smoker & $71(35.5)$ \\
\hline ex-smoker & $51(25.5)$ \\
\hline non-smoker & $78(39.0)$ \\
\hline Family history of atopy & $58(29.0)$ \\
\hline Contact with animals and/or birds & $137(68.5)$ \\
\hline cat & $45(22.5)$ \\
\hline $\operatorname{dog}$ & $102(51.0)$ \\
\hline parrot & $23(11.5)$ \\
\hline canary & $16(8.0)$ \\
\hline other birds & $16(8.0)$ \\
\hline Contact with animals and/or birds in the past & $131(65.5)$ \\
\hline cat & $55(27.5)$ \\
\hline $\operatorname{dog}$ & $96(48.0)$ \\
\hline parrot & $39(19.5)$ \\
\hline canary & $19(9.5)$ \\
\hline $\begin{array}{l}\text { other birds (duck, goose, hen, pigeon } \\
\text { and birds of prey) }\end{array}$ & $30(15.0)$ \\
\hline Using latex gloves in the workplace & $148(74.0)$ \\
\hline Using disinfectants in the workplace & $139(69.5)$ \\
\hline
\end{tabular}

positive SPT results included: D. farinae -32 cases (16\%), D. pteronyssinus - 30 cases $(15 \%)$ and grass pollens $(16.5 \%)$. Eight percent of bird zoo keepers were sensitized to at least one of the bird allergens, most frequently to canary feathers - 9 cases $(4.5 \%)$, parrot feathers -7 cases $(3.5 \%)$, and 7 cases $(3.5 \%)$ to the mix of bird feathers.
The results of allergen-specific serum IgE are presented in Table 3. A total of $72 \%$ of all participants had at least one allergen-specific IgE to bird allergens. Allergenspecific IgE against particular factors was detected in the respective cases, namely against canary feathers in 58 cases $(29 \%)$, against parrot feathers - in 50 cases $(25 \%)$, against pigeon feathers - in 41 cases $(20.5 \%)$, against 
Table 2. The results of SPTs to common and bird allergens and evaluation of the total IgE level

\begin{tabular}{lc}
\hline \multicolumn{1}{c}{ SPTs to } & Whole group $(\mathrm{N}=200)$ \\
$\mathrm{n}(\%)$
\end{tabular}

* Alternaria tenuis, Botrytis cinerea, Cladosporium herbarum, Culvularia lunata, Helminthosporium, Fusarium moniliforme.

**Aspergillus fumigatus, Mucor mucedo, Penicillium notatum, Pullularia pullulans, Rhizopus nigricans, Serpula lacrimans.

\# Alder, hazel, poplar, elm, willow.

\#\# Birch, beech, oak, plane tree.

Table 3. The results of asIgE to bird allergens

\begin{tabular}{lc}
\hline \multicolumn{1}{c}{ asIgE in serum } & $\begin{array}{c}\text { Whole group }(\mathrm{N}=200) \\
\mathrm{n}(\%)\end{array}$ \\
\hline $\begin{array}{l}\text { Specific IgE level to bird allergens } \\
\text { Presence of asIgE to }\end{array}$ & $144(72.0)$ \\
canary feathers (e009) & \\
parrot feathers (e010) & $58(29.0)$ \\
pigeon feathers (e011) & $50(25.0)$ \\
\hline
\end{tabular}


Table 3. The results of asIgE to bird allergens - cont.

\begin{tabular}{lc}
\hline \multicolumn{1}{c}{ asIgE in serum } & Whole group $(\mathrm{N}=200)$ \\
$\mathrm{n}(\%)$
\end{tabular}

pigeon serum - in 60 cases (30\%), against canary serum — in 49 cases (24.5\%), and against parrot serum — in 49 cases $(24.5 \%)$.

We found that 16 persons were positive both for SPTs and/or asIgE to bird allergens, and 13 of them showed both SPTs and asIgE tests results positive for the same bird allergen (Table 4).

\section{Symptoms reported by workers}

All symptoms reported within the group of bird zookeepers in the questionnaire are presented in Table 5.

The following symptoms were recorded in the respective numbers of cases: rhinitis in 62 subjects $(42.2 \%)$, conjunctivitis in 42 cases (28.6\%), lower airways symptoms (dyspnoea, wheezing, chest tightness or cough)

Table 4. Combination of results in a group of persons $(\mathrm{N}=16)$ with positive SPTs and asIgE results to birds allergens

\begin{tabular}{|c|c|c|c|c|c|c|c|c|c|c|}
\hline $\begin{array}{l}\text { Initials of } \\
\text { persons }\end{array}$ & $\begin{array}{l}\text { SPT to bird } \\
\text { allergens }\end{array}$ & $\begin{array}{l}\text { SPT to } \\
\text { parrot } \\
\text { feathers }\end{array}$ & $\begin{array}{l}\text { SPT to } \\
\text { canary } \\
\text { feathers }\end{array}$ & $\begin{array}{c}\text { asIgE } \\
\text { to bird } \\
\text { allergens }\end{array}$ & $\begin{array}{l}\text { asIgE } \\
\text { e009 }\end{array}$ & $\begin{array}{l}\text { asIgE } \\
\mathrm{e} 010\end{array}$ & $\begin{array}{l}\operatorname{asIgE} \\
\mathrm{e} 011\end{array}$ & $\begin{array}{l}\operatorname{asIgE} \\
\mathrm{e} 013\end{array}$ & $\begin{array}{l}\text { asIgE } \\
\text { e014 }\end{array}$ & $\begin{array}{l}\text { asIgE } \\
\text { e016 }\end{array}$ \\
\hline A.K. & + & - & + & + & - & 1.7 & - & 1.3 & 1.6 & - \\
\hline K.F & + & + & - & + & 1.4 & - & 2.0 & 2.0 & 1.1 & - \\
\hline B.K & + & + & + & + & 1.7 & 2.1 & 2.1 & - & 1.9 & - \\
\hline E.J. & + & - & - & + & 1.7 & 2.1 & 2.1 & - & 1.9 & - \\
\hline S.S. & + & + & + & + & 4.2 & - & 3.2 & 4.5 & 4.3 & 4.2 \\
\hline W.D. & + & - & - & + & - & - & 1.6 & - & 1.5 & - \\
\hline J.G. & + & - & + & + & - & - & - & - & - & 2.7 \\
\hline K.S. & + & - & + & + & 1.1 & - & - & - & - & - \\
\hline Sz.B. & + & + & - & + & 2.0 & - & - & - & 2.0 & - \\
\hline K.R. & + & + & - & + & - & - & 2.1 & - & 1.5 & - \\
\hline T.B. & + & + & - & - & - & - & - & - & - & - \\
\hline J.P. & + & - & + & + & - & - & - & 2.5 & - & - \\
\hline A.B. & + & - & + & + & - & - & 1.1 & 2.1 & 2.5 & 1.0 \\
\hline W.H. & + & + & - & + & 1.6 & - & - & - & 1.6 & 1.5 \\
\hline M.Ś. & + & - & + & - & - & - & - & - & - & - \\
\hline M.A. & + & - & + & - & - & - & - & - & - & - \\
\hline
\end{tabular}

+ Positive. - Negative. 
Table 5. Symptoms reported by all bird zookeepers on the basis of the questionnaire

\begin{tabular}{|c|c|c|c|}
\hline Question & $\begin{array}{l}\text { Whole group } \\
(\mathrm{N}=200) \\
\mathrm{n}(\%)\end{array}$ & $\begin{array}{c}\text { Persons with allergy } \\
\text { to bird allergens } \\
\text { (asIgE and/or SPT positive) } \\
(\mathrm{N}=147) \\
\mathrm{n}(\%)\end{array}$ & $\begin{array}{l}\text { Persons without allergy } \\
\text { to bird allergens } \\
\text { (asIgE and SPT negative) } \\
(\mathrm{N}=53) \\
\mathrm{n}(\%)\end{array}$ \\
\hline \multicolumn{4}{|l|}{ Clinical symptoms generally } \\
\hline $\begin{array}{l}\text { symptoms from the lower part of } \\
\text { the respiratory tract }\end{array}$ & $51(25.5)$ & $36(24.5)$ & $15(28.3)$ \\
\hline $\begin{array}{l}\text { at least one symptom from } \\
\text { the respiratory tract }\end{array}$ & $99(49.5)$ & $70(47.6)$ & $29(54.7)$ \\
\hline dyspnoea & $25(12.5)$ & $20(13.6)$ & $5(9.4)$ \\
\hline cough & $43(21.5)$ & $31(21.1)$ & $12(22.6)$ \\
\hline nasal symptoms & $84(42.0)$ & $62(42.2)$ & $22(41.5)$ \\
\hline eye symptoms & $57(28.5)$ & $42(28.6)$ & $15(28.3)$ \\
\hline skin symptoms & $32(16.0)$ & $21(14.3)$ & $11(20.8)$ \\
\hline \multicolumn{4}{|l|}{$\begin{array}{l}\text { Clinical symptoms connected with } \\
\text { the workplace }\end{array}$} \\
\hline $\begin{array}{l}\text { symptoms from the lower part of } \\
\text { the respiratory tract }\end{array}$ & $28(14.0)$ & $20(13.6)$ & $8(15.1)$ \\
\hline $\begin{array}{l}\text { at least one symptom from } \\
\text { the respiratory tract }\end{array}$ & $40(20.0)$ & $29(19.7)$ & $11(20.8)$ \\
\hline dyspnoea & $14(7.0)$ & $11(7.5)$ & $3(5.7)$ \\
\hline cough & $20(10.0)$ & $15(10.2)$ & $5(9.4)$ \\
\hline nasal symptoms & $33(16.5)$ & $22(15.0)$ & $11(20.8)$ \\
\hline eye symptoms & $27(13.5)$ & $18(12.2)$ & $9(17.0)$ \\
\hline skin symptoms & $12(6.0)$ & $11(7.5)$ & $1(1.9)$ \\
\hline $\begin{array}{l}\text { allergy symptoms in the } \\
\text { workplace }\end{array}$ & $58(29.0)$ & $39(26.5)$ & $19(35.8)$ \\
\hline
\end{tabular}

in 36 cases (24.5\%). In total, 39 patients (26.5\%) were diagnosed with an occupational allergy. Occupational rhinitis was found in $22(15 \%)$ cases, occupational asthma was reported among 20 (13.6\%) subjects, occupational conjunctivitis was reported in $18(12.2 \%)$ cases, occupational skin diseases were diagnosed in $11(7.5 \%)$ cases (Table 5).

Univariate analysis showed that none of the parameters analyzed in Table 6 is a risk factor of sensitization to bird allergens in the analyzed group $(\mathrm{N}=200)$.
Statistical analysis revealed that people who had occupational contact with birds from 6 and 10 years more often complained of work-related allergy symptoms in the workplace OR $=4.59$ (95\% CI: 1.06-27.46) (Table 7). This observation was not confirmed by multivariate logistic regression analysis ( $\mathrm{p}=0.0825, \mathrm{OR}=2.03,95 \% \mathrm{CI}$ : 0.9-4.56). Univariate analysis did not confirm that any of the examined risk factors (Table 8) was significantly associated with an occupational respiratory system allergy in the analyzed group. 
Table 6. Risk factors of sensitization to bird allergens using univariate analysis in the whole group $(\mathrm{N}=200)$

\begin{tabular}{|c|c|c|c|}
\hline Analyzed parameter & $\begin{array}{c}\text { Subject sensitized } \\
\text { to bird allergens } \\
(\mathrm{N}=147) \\
\mathrm{n}(\%)\end{array}$ & $\begin{array}{l}\text { Subject not sensitized } \\
\text { to bird allergens } \\
\qquad \begin{array}{c}\mathrm{N}=53) \\
\mathrm{n}(\%)\end{array}\end{array}$ & OR $(95 \% \mathrm{CI})$ \\
\hline Male & $83(56.5)$ & $26(49.1)$ & $1.35(0.68-2.65)$ \\
\hline Female & $64(43.5)$ & $27(50.9)$ & $0.74(0.38-1.46)$ \\
\hline \multicolumn{4}{|l|}{ Duration of work with birds (years) } \\
\hline$<5$ & $28(19.0)$ & $12(22.6)$ & $0.8(0.36-1.90)$ \\
\hline $6-10$ & $32(21.8)$ & $7(13.2)$ & $1.83(0.72-5.25)$ \\
\hline$>11$ & $87(59.2)$ & $34(64.2)$ & $0.81(0.40-1.62)$ \\
\hline Current smokers & $51(34.7)$ & $20(37.7)$ & $0.88(0.44-1.79)$ \\
\hline Family history of atopy & $41(27.9)$ & $17(32.0)$ & $0.82(0.40-1.74)$ \\
\hline Animals at home & $105(71.4)$ & $32(60.4)$ & $1.64(0.80-3.31)$ \\
\hline Birds at home & $25(17.0)$ & $7(13.2)$ & $1.35(0.52-3.94)$ \\
\hline \multicolumn{4}{|l|}{ Occupational exposure to } \\
\hline parrot & $71(48.3)$ & $28(52.8)$ & $0.83(0.42-1.64)$ \\
\hline canary & $56(38.1)$ & $23(43.4)$ & $0.80(0.41-1.60)$ \\
\hline pigeon & $65(44.2)$ & $27(50.9)$ & $0.76(0.39-1.50)$ \\
\hline $\begin{array}{l}\text { other birds (duck, goose, hen } \\
\text { and birds of prey) }\end{array}$ & $70(47.6)$ & $30(56.6)$ & $0.70(0.35-1.37)$ \\
\hline other animals & $92(62.6)$ & $26(49.1)$ & $1.74(0.88-3.44)$ \\
\hline Positive SPT to common allergens & $46(31.3)$ & $19(35.8)$ & $0.82(0.40-1.68)$ \\
\hline Total IgE level > $100 \mathrm{kU} / \mathrm{l}$ & $42(28.6)$ & $11(20.8)$ & $1.53(0.69-3.60)$ \\
\hline
\end{tabular}

Table 7. Risk factors of occupational allergy using univariate analysis in the whole group ( $\mathrm{N}=200)$

\begin{tabular}{|c|c|c|c|}
\hline Analyzed parameter & $\begin{array}{c}\text { Subject } \\
\text { with occupational allergy } \\
(\mathrm{N}=39) \\
\mathrm{n}(\%)\end{array}$ & $\begin{array}{c}\text { Subject } \\
\text { without occupational allergy } \\
(\mathrm{N}=34) \\
\mathrm{n}(\%)\end{array}$ & OR $(95 \% \mathrm{CI})$ \\
\hline Male & $18(46.2)$ & $18(52.9)$ & $0.76(0.27-2.11)$ \\
\hline Female & $21(53.8)$ & $16(47.1)$ & $1.31(0.47-3.65)$ \\
\hline \multicolumn{4}{|c|}{ Duration of work with birds (years) } \\
\hline$<5$ & $7(17.9)$ & $8(23.5)$ & $0.71(0.19-2.59)$ \\
\hline $6-10$ & $12(30.8)$ & $3(8.8)$ & $4.59(1.06-27.46)^{*}$ \\
\hline$>11$ & $20(51.3)$ & $23(63.6)$ & $0.50(0.17-1.44)$ \\
\hline Current smokers & $12(30.8)$ & $20(58.8)$ & $1.78(0.60-5.32)$ \\
\hline Family history of atopy & $17(43.6)$ & $12(35.3)$ & $1.42(0.50-4.08)$ \\
\hline Animals at home & $28(71.8)$ & $10(29.4)$ & $1.07(0.35-3.31)$ \\
\hline
\end{tabular}


Table 7. Risk factors of occupational allergy using univariate analysis in the whole group $(\mathrm{N}=200)$ - cont.

\begin{tabular}{lccc}
\hline \multicolumn{1}{c}{ Analyzed parameter } & $\begin{array}{c}\text { Subject } \\
\text { with occupational allergy } \\
(\mathrm{N}=39) \\
\mathrm{n}(\%)\end{array}$ & $\begin{array}{c}\text { Subject } \\
\text { without occupational allergy } \\
\mathrm{N}=34) \\
\mathrm{n}(\%)\end{array}$ & OR (95\% CI) \\
\hline $\begin{array}{l}\text { Birds at home } \\
\text { Occupational exposure to: }\end{array}$ & $7(17.9)$ & $4(11.8)$ & $1.64(0.37-8.39)$ \\
$\quad$ parrot & $26(66.7)$ & & \\
$\quad$ canary & $17(43.6)$ & $15(55.9)$ & $2.53(0.89-7.30)$ \\
pigeon & $19(48.7)$ & $12(35.3)$ & $1.42(0.50-4.08)$ \\
$\quad$ other birds (duck, goose, hen & $21(53.8)$ & $14(41.2)$ & $1.36(0.49-3.81)$ \\
and birds of prey) & & $18(52.9)$ & $1.04(0.37-2.88)$ \\
$\begin{array}{l}\text { Positive SPT to common allergens } \\
\text { Total IgE level > 100k U/l }\end{array}$ & $20(51.3)$ & & \\
\hline
\end{tabular}

$* \mathrm{p}<0.05$.

Table 8. Risk factors of occupational respiratory tract allergy using univariate analysis in the whole group $(\mathrm{N}=200)$

\begin{tabular}{lccc}
\hline \multicolumn{1}{c}{ Analyzed parameter } & $\begin{array}{c}\text { Subjects with occupational } \\
\text { airway allergy } \\
\text { asthma and/or allergic } \\
\text { rhinitis }(\mathrm{N}=29)\end{array}$ & $\begin{array}{c}\text { Subjects without occupational } \\
\text { airway allergy } \\
(\mathrm{N}=42)\end{array}$ & OR (95\% CI) \\
$\mathrm{n}(\%)$ & $22(52.4)$ & $0.64(0.22-1.85)$ \\
\hline Male & $12(41.4)$ & $20(47.6)$ & $1.56(0.54-4.53)$ \\
Female & $17(58.6)$ & & \\
Duration of work with birds (years) & & $10(23.8)$ & $0.67(0.16-2.50)$ \\
$<5$ & $5(17.2)$ & $5(11.9)$ & $2.82(0.70-12.28)$ \\
6-10 & $8(27.6)$ & $27(64.3)$ & $0.68(0.23-2.01)$ \\
$>11$ & $16(55.2)$ & $15(35.7)$ & $0.81(0.26-2.47)$ \\
Current smokers & $9(31.0)$ & $12(28.6)$ & $2.03(0.67-6.14)$ \\
Family history of atopy & $13(44.8)$ & $23(54.8)$ & $1.84(0.61-5.67)$ \\
Animals at home & $20(69.0)$ & $5(11.9)$ & $1.93(0.43-8.91)$ \\
Birds at home & $6(20.7)$ & & \\
Occupational exposure to & & $20(47.6)$ & $1.56(0.54-4.53)$ \\
parrot & $17(58.6)$ & $17(40.5)$ & $0.77(0.26-2.29)$ \\
canary & $10(34.5)$ & $20(47.6)$ & $0.89(0.31-2.56)$ \\
pigeon & $13(44.8)$ & $23(54.8)$ & $0.67(0.23-1.93)$ \\
$\quad$ other birds (duck, goose, hen & $13(44.8)$ & $14(33.3)$ & $1.63(0.55-4.79)$ \\
and birds of prey) & $13(44.8)$ & $8(19.0)$ & $3.00(0.91-10.10)$ \\
Positive SPT to common allergens & $12(41.4)$ & & \\
Total IgE level > 100 kU/1 & & &
\end{tabular}


Table 9. Results of spirometry among 200 bird zookeepers

\begin{tabular}{|c|c|c|c|c|c|}
\hline Group & $\begin{array}{c}\text { EVC } \\
(\%) \\
\text { (mean } \pm \text { SD) }\end{array}$ & $\begin{array}{c}\text { FEV1 } \\
(\%) \\
(\text { mean } \pm \text { SD })\end{array}$ & $\begin{array}{c}\text { FVC } \\
(\%) \\
\text { (mean } \pm \text { SD) }\end{array}$ & $\begin{array}{c}\mathrm{PEF} \\
(\%) \\
(\text { mean } \pm \mathrm{SD})\end{array}$ & $\begin{array}{c}\text { FEV1/FVC } \\
(\%) \\
(\text { mean } \pm \text { SD) }\end{array}$ \\
\hline $\begin{array}{l}\text { Whole group }(\mathrm{N}=200) \\
\text { (min., max.) }\end{array}$ & $\begin{array}{c}93.13 \pm 14.25 \\
(58 ; 141)\end{array}$ & $\begin{array}{c}99.81 \pm 12.91 \\
(46 ; 142)\end{array}$ & $\begin{array}{c}97.82 \pm 12.74 \\
(61 ; 140)\end{array}$ & $\begin{array}{c}95.63 \pm 17.71 \\
(35 ; 145)\end{array}$ & $\begin{array}{c}106.34 \pm 9.83 \\
(75 ; 165)\end{array}$ \\
\hline $\begin{array}{l}\text { Subjects with occupational } \\
\text { airway allergy }(\mathrm{N}=29) \\
\text { (min., max.) }\end{array}$ & $\begin{array}{c}101.1 \pm 17.06 \\
(79 ; 141)\end{array}$ & $\begin{array}{c}100.83 \pm 12.27 \\
(84 ; 128)\end{array}$ & $\begin{array}{c}99.31 \pm 14.58 \\
(77 ; 127)\end{array}$ & $\begin{array}{c}98 \pm 12.91 \\
(78 ; 133)\end{array}$ & $\begin{array}{c}106.24 \pm 8.24 \\
(81 ; 117)\end{array}$ \\
\hline
\end{tabular}

EVC - Expiratory Vital Capacity.

FEV1 - Forced Expiratory Volume in 1 sec.

PEF - Peak Expiratory Flow.

Table 10. Results of cytograms from nose swabs in 200 bird zookeepers

\begin{tabular}{|c|c|c|c|c|c|c|}
\hline Group & $\begin{array}{l}\mathrm{Na} \\
(\%)\end{array}$ & $\begin{array}{l}\mathrm{Ne} \\
(\%)\end{array}$ & $\begin{array}{l}\text { Eo } \\
(\%)\end{array}$ & $\begin{array}{c}\mathrm{Ba} \\
(\%)\end{array}$ & $\begin{array}{c}\mathrm{Li} \\
(\%)\end{array}$ & $\begin{array}{l}\text { Mo } \\
(\%)\end{array}$ \\
\hline $\begin{array}{l}\text { Whole group }(\mathrm{N}=200) \\
\text { (min.; max.) }\end{array}$ & $\begin{array}{c}39.21 \pm 24.16 \\
(1 ; 94)\end{array}$ & $\begin{array}{c}59.84 \pm 24.39 \\
(6 ; 98)\end{array}$ & $\begin{array}{c}1.15 \pm 5.69 \\
(0 ; 66)\end{array}$ & 0 & 0 & $\begin{array}{c}0.11 \pm 0.33 \\
(0 ; 2)\end{array}$ \\
\hline $\begin{array}{l}\text { Subjects with occupational airway } \\
\text { allergy }(\mathrm{N}=29) \\
\text { (min.; max.) }\end{array}$ & $\begin{array}{c}43.59 \pm 27.91 \\
(6 ; 34)\end{array}$ & $\begin{array}{c}53.72 \pm 29.38 \\
(6 ; 94)\end{array}$ & $\begin{array}{c}3.27 \pm 12.92 \\
(0 ; 66)\end{array}$ & 0 & 0 & $\begin{array}{l}0.10 \pm 0.31 \\
(0 ; 1)\end{array}$ \\
\hline
\end{tabular}

$\mathrm{Na}$ - epithelial cells , $\mathrm{Ne}$ - neutrophils, Eo - eosinophils, Ba — basophils , Li — lymphocytes , Mo — monocytes.

The results of spirometry were similar in both examined groups, as shown in Table 9.

More eosinophils were found in cytograms from nose swabs of bird zookeepers with an occupational airway respiratory allergy (Table 10).

\section{DISCUSSION}

Allergen exposure may occur from contact with bird feathers, serum or droppings. Bird droppings may contain excreted serum protein antigens, they may also include bacterial endotoxin and other biological non-specific substances $[10,11]$. Feathers have been known as a source of allergens since 1920 [12].

The most frequent allergens yielding positive SPT results within the total studied population were $D$. farina 32 cases $(16 \%)$, D. pteronyssinus -30 cases $(15 \%)$ and grass pollens $(16.5 \%)$. There are many articles proving that feather mites compose a major source of clinicallyrelevant allergens for pigeon breeders [13-16].

Eight percent of 200 bird zookeepers were sensitized to at least one of the bird allergens, most frequently to canary feathers -9 cases $(4.5 \%)$, parrot feathers $-7 \mathrm{ca}-$ ses $(3.5 \%)$, and 7 cases $(3.5 \%)$ to a mix of bird feathers. In our earlier work, published in 2002, 45 (66.1\%) subjects out of the group of 68 examined zoo animal keepers revealed positive skin reaction to any inhalant allergen, while 12 (17.6\%) workers within the same cohort - only to feather allergens [16]. In the examined group, allergen-specific $\mathrm{IgE}$ against canary feathers was detected in 58 cases $(29 \%)$, against parrot feathers in 50 cases (25\%), against pigeon feathers - in 41 cases $(20.5 \%)$, against pigeon serum - in 60 cases $(30 \%)$, against canary serum - in 49 cases $(24.5 \%)$, against 
parrot serum - in 49 cases (24.5\%). Additionally, we found that 16 persons had both positive SPT and asIgE to bird allergens. Both SPT and asIgE were positive to the same bird allergen in 13 cases.

Some data obtained from the general population indicates that positive results in intracutaneous and SPTs with feather allergens may occur in 20-60\% of patients suspected of allergy to feathers [17-18]. In the study published by Kilpio et al. [19], 24 patients (19\%) out of 269 adult subjects with suspected allergic cutaneous or respiratory symptoms and $14 \%$ of the patients with a positive reaction to any inhalant allergen (177 subjects) reacted to commercial feather extracts.

Occupational allergy was diagnosed in $39(26.5 \%)$ cases. Occupational rhinitis was found in $22(15 \%)$ cases, occupational asthma was reported among $20(13.6 \%)$ subjects, occupational conjunctivitis was reported in 18 (12.2\%) cases, while occupational skin diseases were diagnosed in $11(7.5 \%)$ cases. In the research carried out in the United Kingdom during 1999-2000, the estimated incidence rate of asthma attributable to birds amounted to $23.9 / 1000 /$ year [20]. In another study, up to $17.4 \%$ of poultry farmers reported symptoms of asthma [2]. Rees et al. [21] after the examination of 134 poultry workers found that significantly more poultry workers, comparing to the control group, complained of respiratory, ocular, nasal and dermal symptoms, resulting from exposure to irritating agents at work. Poultry workers included in that study reported symptoms consistent with asthma which occurred with rising frequency of $3 \%, 4 \%$ and $13 \%$ for the corresponding increasing exposure: low, medium and high, respectively. Unexpectedly, univariate analysis did not reveal a significant association between occupational contact with birds and sensitization to bird allergens or with an occupational respiratory system allergy in the analyzed group. Similarly, the present study did not confirm a higher frequency of work-related allergic symptoms at the workplace within the group of people with occupational exposure to bird allergens during the period ranging from 6 to 10 years. The obtained results appeared to be somewhat disappointing. In our study $68.5 \%$ of all participants reported a current contact with an animal at home, including birds in some cases, so that fact may partly explain why the authors did not find the occupational contact with bird to be a statistically significant variable in the final analysis. Perhaps the data would be different if the authors analyzed more precisely the character of occupational exposure - specific job, the intensity of exposure to bird allergens, and the frequency of use of personal protective equipment. At present, we can only suppose that, similarly as in laboratory animal allergy, many personal and exposure variables may participate in the development of sensitization and occupational allergy [22] and that further research in this area will bring new insight into bird exposures and allergic responses.

The higher number of eosinophils was found in cytograms from nose swab of bird zookeepers with occupational airway respiratory allergy. During the allergic inflammation process they are attracted to the airways, then they migrate through the vascular endothelium to airway epithelium and release eosinophilic toxic products, lipid mediators, oxygen free radicals and cytokines [23]. In the authors' opinion, the subjects who suffer from an occupational allergy involving airways seem to have a greater deal of airway inflammation. We also think that a linear association between the level of sensitization and the cell count analyzed in the cytograms from nose swab does not exist - this hypothesis deserves further investigations.

\section{CONCLUSIONS}

The findings indicate that occupational allergy to birds is an important health problem among zoo bird keepers in Poland. 


\section{REFERENCES}

1. Bar-Sela S, Teichtahl H, Lutsky I. Occupational asthma in poultry workers. J Allergy Clin Immunol 1984;73(2):271-5.

2. Kimbell-Dunn M, Bradshaw L, Slater T, ErkinjunttiPekkanen R, Fiswick D, Pearce N. Asthma and allergy in New Zealand farmers. Am J Ind Med 1999;35(1):51-7.

3. Korn DS, Florman AL, Gribetz I. Recurrent pneumonitis with hypersensitivity pneumonitis to hen litter. JAMA 1968;205:114.

4. Swiderska-Kiełbik S, Krakowiak A, Wiszniewska M, Dudek W, Kowalczyk M, Walusiak-Skorupa J, et al. Workrelated respiratory symptoms in bird zoo-keepers-questionnaire data. Int J Occup Med Environ Health 2009;22(4):393-9. DOI 10.2478/v10001-009-0035-2.

5. Tauer-Reich I, Fruhmann G, Czuppon AB, Baur X. Allergens causing bird fancier's asthma. Allergy 1994;49:448-53.

6. Swiderska-Kiełbik S, Krakowiak A, Wiszniewska M, Dudek W, Walusiak-Skorupa J, Krawczyk-Szulc P, et al. Health hazards associated with occupational exposure to birds. Med Pr 2010;61(2):213-22 [in Polish].

7. Johansson SG, Hourihane JOB, Bousquet J, BruijnzeelKoomen C, Dreborg S, Haahtela T, et al. A revised nomenclature for allergy. An EAACI position statement from the EAACI nomenclature task force. Allergy 2001;56:813-23.

8. Reininger R, Swoboda I, Bohle B, Hauswirth AW, Valent P, Rumpold $\mathrm{H}$, et al. Characterization of recombinant cat albumin. Clin Exp Allergy 2003;33:1695-1702.

9. Krakowiak A, Pałczyński C. Allergy from exposure to animals. [In]: Pałczyński C, Kieć-Świerczyńska M, Walusiak J, editors. Occupational allergy. Łódź: Instytut Medycyny Pracy; 2008. p. 366-87 [in Polish].

10. Bulmer AC, Bulmer GS. Incidence of histoplasmin hypersensitivity in the Philippines. Mycopathologia 2001;149(2):69-71.

11. Lutsky I, Bas-Sela S. Northern fowl mite (Ornithonyssus sylvarium) in occupational asthma of poultry workers. Lancet 1982;2:874-5.

12. Voorhorst R, Spieksma FThM, Varekamp H. Houst-dust atopy and the houst-dust mite Dermatophagoides pteronyssinus (Trouessart, 1897). Leiden: Staflen; 1969.
13. Colloff MJ, Merrett TG, Merrett J, McSharry C, Boyd G. Feather mites are potentially an important source of allergens for pigeon and budgerigar keepers. Clin Exp Allergy 1997;27:60-7.

14. Solarz K, Szilman P, Szilman E. Occupational exposure to allergenic mites in a Polish zoo. Ann Agric Environ Med 2004;11:27-33.

15. Krakowiak A, Pałczyński C, Walusiak J, Wittczak T, Ruta U, Dudek W, et al. Allergy to animal fur and feathers among zoo workers. Int Arch Occup Environ Health 2002;75(Suppl):S113-6.

16. Walusiak J, Krawczyk-Adamus P, Hanke W, Wittczak T, Pałczyński C. Small nonspecialized farming as a protective factor against immediate-type occupational respiratory allergy? Allergy 2004;59:1294-300.

17. Geller M. Respiratory atopy in Rio de Janerio. Ann Allergy 1990;64:171-3.

18. Chapman J, Williams S. Aeroallergens of the southeast Missouri area: a report of skin test frequencies and air sampling data. Ann Allergy 1984;52:411-8.

19. Kilpio K, Makinen-Kiljunen S, Haahtela T, Hannuksela M. Allergy to feathers. Allergy 1998;53:159-64.

20. Draper A, Newman Taylor A, Cullinan P. Estimating the incidence of occupational asthma and rhinitis from laboratory animals in the UK, 1999-2000. Occup Environ Med 2003;60:604-5.

21. Rees D, Nelson G, Kiełkowski D, Wassrfall C, da Costa A. Respiratory health and immunological profile of poultry workers. S Afr Med J 1998;(9):1110-7.

22. Pacheco KA. New insights into laboratory animal exposures and allergic responses. Curr Opin Allergy Clin Immunol 2007;7:156-61.

23. Filipović M, Cekić S. The role of eosinophils in asthma. Med Biol 2001;8:6-10.

This work is available in Open Access model and licensed under a Creative Commons Attribution-NonCommercial 3.0 Poland License - http://creativecommons.org/ licenses/by-nc/3.0/pl/deed.en. 